\title{
The Ecological Intensity of Well-Being in Developing Countries: A Panel Data Analysis
}

\author{
Hina Irshad ${ }^{1}$ \\ Higher Education Department, Government of the Punjab, Punjab, Pakistan \\ Anwar Hussain \\ Department of Economics and Development Studies, University of Swat, \\ Khyber Pakhtoonkhwa Province, Pakistan \\ Muhammad Irfan Malik \\ Department of Economics, School of Social Sciences and Humanities, \\ National University of Science and Technology (NUST), Islamabad, Pakistan
}

\section{Abstract}

Recent sustainability research into balancing the demands for ecosystem services and benefits in the form of human well-being has developed into a study of the ecological intensity of well-being (EIWB). Research into EIWB focuses on its reduction, as a pathway to sustainability. Here, we present a revised measure of EIWB by using a ratio of ecological footprint per capita (EF) to infant survival rate (ISR). EF per capita is included as an indicator of anthropogenic environmental stress and ISR serves as a measure of well-being, well suited to the context of developing countries. By using panel data for 81 developing countries, we mainly draw our hypothesis from a modernization perspective and check the effects of economic growth and urbanization on EIWB. The results indicate that economic growth has a positive effect on EIWB; also increasing urbanization can increase EIWB. Overall, these findings suggest that developing countries are less likely to achieve sustainability with current modernization practices.

Keywords: ecological footprint, ecological intensity of well-being (EIWB), environmental Kuznets curve, infant survival rate, sustainability

Recommended citation (APA 7th ed.)

Irshad, H., Hussain, A., \& Malik, M. I. (2021). The ecological intensity of well-being in developing countries: A panel data analysis. Human Ecology Review, 27(1), 79-99. doi.org/10.22459/HER.27.01.2021.05

1 Corresponding author: hina.irshad@ymail.com. 


\section{Introduction}

The inhabitants of the world depend upon the earth's ecosystem and make use of environmental amenities to sustain their lives. However, societal demands on the environment are multiplying due to current socioeconomic practices, which results in increased stress on the environment in various ways. The international ecosystem's capacity to provide environmental services determines the social wellbeing of nations. Therefore, it is crucial to analyze the interrelationship between societal well-being, environmental stress, and economic growth on the grounds of basic sustainability science.

Since the industrial revolution, there has been widespread concern about global environmental issues such as resource scarcities and how changes in the economic system have driven them (Meadows et al., 1972). A significant body of research has focused on the notion that economic growth may be harmful to the environment (Ehrlich \& Holdren, 1971), while the eco-socialist approach maintains that social and technological development will lead to a decrease in population growth and a corresponding decrease in environmental damage (Commoner, 1972; Commoner et al., 1972).

Despite the lack of an absolute consensus, the question of how economic activity affects the environment has remained a popular area of research since the 1960s. In the mid-1990s, various mainstream economists examined the environmental Kuznets curve (EKC) hypothesis ${ }^{2}$ and observed that the EKC argument pertains to environmental impacts (Grossman \& Krueger, 1995; Shafik, 1994; Stern et al., 1996). Similarly, the idea of ecological modernization gained attention worldwide by the late 1990s. Ecological modernization theory (EMT), relies on the assumptions of neoclassical economics and emphasizes the positive role of economic growth and development in achieving sustainability. EMT argues that modern societies have capacity to deal with their environmental crises and emphasizes environmental reforms in societal practices, institutional designs, and policy discourse to reduce environmental impacts (Mol \& Sonnenfeld, 2000). Therefore, conventional research and policy discussions on sustainability presented the idea of measuring the ratio of intensity to efficiency - that is, the national ecological footprint (as a measure of environmental stress) per unit of economic output (GDP, as a surrogate measure of well-being) — and focused on its reduction (Dietz et al., 2012; Timmons Roberts \& Grimes, 1997).

In addition, the body of research focusing on the effects of economic growth on human well-being shows that well-being diminishes beyond the achievement of an adequate affluence level. This finding challenges the proposition of individual

2 The environmental Kuznets curve hypothesis argues that indicators of environmental degradation tend to increase as national economies grow until economic growth reaches a turning point, after which the impacts decline. 
choice to maximize utility in economic theory (Brady et al., 2007; Dietz et al., 2001; Layard, 2010). Therefore, a substantial body of research has questioned the reliance on GDP per capita as measure of well-being and has emphasized using direct indicators of well-being (Costanza et al., 2009; European Commission, 2009).

In 1992, the outcome document of the revolutionary Rio Earth Summit, Agenda 21 presented sustainable consumption as a major policy issue (United Nations Conference on Environment and Development, 1992). Since then, empirical research has focused on consumption as a major aspect of environmental sustainability, and two strands of interpretation on sustainable consumption have appeared in the literature (Knight \& Rosa, 2011). The first strand was based on the assumption in neoclassical economics that consumption equates with utility, and advocated consuming differently rather than reducing consumption ( $\mathrm{Mol} \&$ Spaargaren, 2004). The second strand advocated for an absolute reduction in consumption, as consumption and well-being levels were not found to be tightly coupled (Seyfang, 2009). In this context, a significant body of research has further demonstrated that human well-being is not in lockstep with consumption of environmental resources and other forms of environmental stressors (Dietz et al., 2009; Steinberger \& Timmons Roberts, 2010; Steinberger et al., 2012). Particularly, Dietz et al. (2009) came up with an interesting finding that human well-being may be improved without increasing pressure on environmental resources.

These findings opened new avenues for researchers. This sustainability research focused on minimizing pressure on ecosystem services while maximizing human well-being (Knight \& Rosa, 2011). A substantial body of sustainability research conceptualized this idea as ecological intensity of well-being (EIWB), defined as the ratio of ecological footprint (EF) per capita (as an indicator of anthropogenic environmental stress) to average life expectancy at birth (as a broad measure of human well-being). These studies emphasize the reduction of EIWB, which is desirable as an effective sustainability strategy, and attempt to identify the potential of various factors that shape EIWB (Dietz et al., 2009, 2012; Jorgenson \& Dietz, 2015; Knight \& Rosa, 2011).

Currently, an increase in human-induced pressure on the ecosystem is producing an alarming impact in the form of global environmental changes. The potential effects of environmental degradation are particularly important for developing countries that are experiencing major economic and demographic transitions (MartínezZarzoso \& Maruotti, 2011). Developing countries are home to 5 billion of the world's 7 billion people who depend on the exploitation of natural resources for their livelihoods and who are thus vulnerable to the effects of climate change. Also, conventional economic growth patterns-rapid urbanization and environmental degradation-are posing new challenges. Therefore, a practical understanding of the progress towards the key objectives of sustainability is essential and urgent for these countries. 
The present study attempts to contribute to the understanding of EIWB and the extent to which it is affected by major socioeconomic factors in developing countries. Mainly, we assess the effect of key modernization indicators on EIWBthat is, whether an increase in economic growth tends to decrease EIWB or not. We check whether there is an EKC relationship between EIWB and affluence levels. Additionally, we check whether increased urbanization tends to decrease EIWB. If the modernization of developing economies is beneficial for sustainability, then the environmental cost of generating human well-being should decline with higher economic growth and urbanization.

International development organizations aim at achieving a better quality of life for people, as well as environmental protection, along with a higher level of economic development as a pathway to sustainable development. Therefore, identifying the potential major drivers behind EIWB will help to shape credible institutional policies in developing countries.

\section{Materials and methods}

\section{The data set}

The study uses panel data, covering 1989-2013, from 81 developing countries, and nation-states are the unit of analysis. This yields a balanced data set of 25 annual observations and a sample of 2,025 total observations. Lower- and upper-middleincome countries in the national income classifications of the World Bank (2015) are categorized as developing countries ${ }^{3}$ and we selected the sample countries based on data availability (see Appendix Table 1). Following other recent studies, countries where the calculation of EF contains no temporal inconsistencies are included. ${ }^{4}$ Only nations with a population of at least 1 million are included in the study. Data on GDP per capita, infant mortality rate, urbanization, and population density were sourced from the World Development Indicators (WDI) at the World Bank (n.d.). EF data were retrieved from the Global Footprint Network, USA.

\section{Dependent variable: Ecological intensity of well-being (EIWB)}

Several attempts have been made in the literature and policy discussions to operationalize the environmental intensity (or efficiency) of well-being. Consistent with the conventional approach of cost-benefit analysis in economic theory, the search for an appropriate measure initially resulted in developing indicators for environmental stress (cost) and for well-being (benefit).

3 Lower-middle-income countries: gross national income (GNI) per capita between USD1,006 and USD3,955. Upper-middle-income countries: GNI per capita between USD3,956 and USD12,235 (www.worldbank.org).

4 The possibility of temporal anomalies in calculations of EF for some countries may lead to invalid findings (Jorgenson \& Clark, 2011). 
Dietz et al. (2001) presented this measure by calculating a ratio of infant mortality (which they converted to infant survival) and a joint index of environmental system indicators and EF per capita. Prescott-Allen (2001) developed a similar measure by computing the ratio of a composite index of objective measures of well-being and a combined environmental quality index. Likewise, Marks et al. (2006) presented the Happy Planet Index as a ratio of the product of average life expectancy and life satisfaction over EF per capita.

Dietz et al. (2009), however, presented an innovative approach and used a stochastic frontier production model to estimate the environmental efficiency of well-being and included affluence, education, and EF as the determinants of average life expectancy. Also, Knight and Rosa (2011) introduced an alternative measure by regressing a subjective measure of well-being-average life satisfaction —on EF per capita and calculating the residuals. A positive residual showed higher well-being relative to $\mathrm{EF}$ and vice versa.

Later, to remain consistent with the EKC proposition, where an increase in the selected dependent variable is undesirable, the concept of ecological intensity of well-being (EIWB)was presented. For instance, the EIWB measure was developed as a ratio between $\mathrm{EF}$, as an environmental stressor, and an established well-being measure such as average life expectancy (Dietz et al., 2012; Jorgenson, 2014; Jorgenson \& Dietz, 2015).

While a variety of measures have been used so far, several conditions must be met regarding the choice of indicators for well-being and environmental stress. For example, the selected measures should not only be consistent with their conventional meanings, but should also be harmonized with the general socioeconomic conditions of the sample nations, with large data sets available for many countries (Dietz et al., 2012).

\section{Infant mortality rate (IMR) (converted to infant survival rate)}

The widespread agreement that human well-being should be indicated by variables other than GDP per capita led to the development of the basic need agenda and Physical Quality of Life Index in the 1970s. A similar multidimensional view of development has been advocated by the United Nations Development Programme (UNDP, 2009) in the Human Development Reports. ${ }^{5}$ Since then, health variablesfor instance, life expectancy at age one and infant or maternal mortality-as well as education indicators have been used to indicate a country's well-being status (Hanmer et al., 2003).

5 See: www.hdr.undp.org/. 
Regardless of the World Bank's emphasis on an economic growth-led development strategy (Ravallion, 1997), the Millennium Development Goals set out in 2001 adopt a variety of well-being goals - including the reduction by two-thirds of infant and under-five mortality by 2015 - as poverty reduction targets, particularly in low-income and developing countries. The importance of infant mortality rates was again underlined by the United Nations (UN) Sustainable Development Goals (SDGs), when they aimed at reducing infant mortality to at least as low as 12 per 1,000 live births as one of the indicators to achieve SDG 3 (UN, 2020).

Generally, the research in environmental social sciences has focused on average life expectancy as a well-being indicator, as it is well measured in most countries (Jorgenson \& Dietz, 2015). However, there are many reasons that $\mathrm{IMR}^{6}$ (converted to infant survival rate) has paramount importance as a well-being indicator. First, it is less likely that IMR is dominated by the affluent as greater wealth can drive average life expectancy upward, but has less effect on IMR (Firebaugh \& Beck, 1994). Second, unlike average life expectancy, IMR has fewer measurement errors, fewer chances of reverse causality with GDP, and a lower likelihood of upwards bias in coefficients of growth (Pritchett \& Summers, 1996). Third, infant mortality is more responsive to changes in socioeconomic and environmental conditions than either literacy or life expectancy because infants, unfortunately, are more vulnerable to these changes than other members of the population (Dietz et al., 2001).

Reidpath and Allotey (2003) argued that, although other measures of population health (such as disability-adjusted life expectancy) may be more comprehensive and reflect a wider population, focusing on more comprehensive measures could cause complexity, and furthermore that collection of the additional data would impose further costs on resource-constrained countries. Thus, IMR remains an important health indicator for whole populations. This, along with relative ease of access to quality data, makes IMR a suitable choice as a well-being indicator for countries with limited resources who require a concise and easily calculated measure of well-being.

For all these reasons, we prefer to use IMR (converted to infant survival rate) as a well-being indicator in this study. Even though IMR has remained a focus of many researchers in demographic and public health, it has rarely been used in the measurement of EIWB of nations. We suggest that future research could employ other well-being measures in the calculation of EIWB, preferably consistent with international human development targets.

6 IMR is calculated by dividing the number of children dying under one year of age by the number of live births during the year, multiplied by 1,000. databank.worldbank.org.

7 See: sustainabledevelopment.un.org/sdgs. 


\section{Ecological footprint (EF)}

The study includes the ecological footprint (EF) per capita of nations as the measure indicating environmental stress. EF measures bioproductive land area (measured in global hectares) required to sustain a population's resource consumption and waste generation (Rees, 1996). It is calculated by adding up cropland, grazing land, fishing grounds, forests, carbon uptake, and built-up land footprints (Lin et al., 2018). ${ }^{8} \mathrm{EF}$ is a comprehensive measure of environmental pressure induced by resource consumption (Dietz et al., 2007; Jorgenson \& Clark, 2011; Rees, 1996), and is considered to be a reliable stress indicator in environmental and social science research.

Although EF is well regarded in scientific and environmental circles, many critiques have been made of its description and method. For example, Fiala (2008) argued that EF underestimates the environmental impacts of intensive production stemming from economic and technological development. Also, some critics point out the omission of key environmental threats like pollution from toxic substances (Dietz et al., 2012) and the lack of attention given to biodiversity loss in the calculation of EF (Özler \& Obach, 2009).

However, Rees (2006) has acknowledged that EF is likely to underestimate impacts as it was primarily developed as a hypothetical measure of anthropogenic stress on the environment, for which it has been less criticized (Dietz et al., 2012; Jorgenson \& Dietz, 2015). More recently, Giampietro and Saltelli (2014) have noted some other methodological flaws. They argue that EF accounting does not capture the present boost in agricultural productivity (biocapacity), which carries an ecological impact. Giampietro and Mayumi (2009) have previously noted that EF doesn't include the requirement of land for producing fuels to meet energy consumption and only considers the requirement of land for $\mathrm{CO}_{2}$ absorption-hence it ignores energy security.

In response, the proponents of EF consider this critique a misinterpretation and have emphasized the need to understand the purpose and scope of this accounting tool to identify research areas for improvements. Galli et al. (2016) argue that EF does not measure energy security per se. Furthermore, it is not a predictive measure of sustainability, nor is it a measure of human impact. Rather, EF accounts compare human demand on Earth's ecosystems to what these ecosystems can renew. Given this knowledge and scope, it should be considered an important but not sufficient minimum reference framework (Borucke et al., 2013; Jorgenson \& Clark, 2011).

Despite these criticisms, EF captures the broad patterns of environmental pressure and available data for most global nations at a given moment: hence, it is broadly accepted throughout the social science disciplines (Jorgenson \& Dietz, 2015). 
Jorgenson and Clark (2011) recognize that EF is conservative, but is nonetheless a comprehensive measure of consumption-driven environmental stress. Therefore, $\mathrm{EF}$ is a sufficiently robust choice as a measure of environmental stress for the purposes of our study.

\section{Independent variables}

Modernization perspectives (economic modernization theory from economics, and ecological modernization theory developed by sociologists), while acknowledging that economic development has generated environmental problems, suggest that further development may alleviate these impacts rather than adding to them (Grossman \& Krueger, 1995; Mol \& Spaargaren, 2000).

Thus, modernization theories are consistent with the assumptions of neoclassical economics and emphasize that higher economic growth is helpful to achieve sustainability. The proposed relationship between economic development and environmental impacts is named the environmental Kuznets curve (EKC). EKC supposedly demonstrates that environmental impacts increase in the early stages of economic development up to a point, then decline with further economic growth (Grossman \& Krueger, 1995).

A wide range of studies in sustainability research have explored the existence of the EKC phenomenon by comparing the outcome variable and the affluence level (GDP per capita) of nations, with most indicating an increase in environmental stress or EIWB at a higher levels of economic development (Dietz et al., 2012; Knight \& Rosa, 2011; York et al., 2003, 2004).

Nevertheless, consistent with modernization theories, we examine the prediction of an EKC relationship between economic development and EIWB. Guided by the discussion in the literature, our study includes GDP per capita as an indicator of economic growth in the nations included in our study. We use both linear and quadratic terms of GDP per capita as independent variables and predict a positive linear and negative quadratic coefficient of GDP per capita, consistent with EKC hypothesis.

In addition to economic development, urbanization is another important indicator of modernization used by EMT theorists because it is associated with many of the institutions of modernity (York et al., 2003). York et al. (2003) have included urbanization as modernization indicator and found that it has a positive effect on national EF. Also, in a cross-national analysis, York et al. (2004) have found that urbanization appears to increase EF. Here, we include urbanization to assess the predictions of EMT theorists by using the percentage of the population living in urban areas as another indicator of modernization, and predicting a negative relationship between urbanization and EIWB, consistent with EMT perspective. 
Furthermore, we include population density as one of the independent variables in our analysis. A range of studies cited here, especially in the research on crossnational assessment of environmental impacts and their determinants, have included population density as an indicator of the geographic conditions of a nation (Lamb et al., 2014; York et al., 2004).

York et al. (2004) have included population density as an indicator of geographic conditions and found a significant negative effect of population density on EF intensity (EF/GDP), suggesting that this effect is likely as it is easier to build mass transportation systems and efficient structures for a compact population. Further, Lamb et al. (2014) found a positive but insignificant effect of population density on territorial carbon emissions. Recently, Bay and Lehmann (2017) have suggested that to achieve sustainability, higher-density cities are socially beneficial, environmentally sound, and economically viable. However, the impact of population density on EIWB remains understudied so far. On this basis we have included population density as another independent variable, as it may have a significant effect on EIWB. Table 1 presents the details of all study variables.

\section{Panel data econometric model}

In econometrics, panel data estimations are an efficient analytical method for handling longitudinal data that contain observations of multiple phenomena over an extended time period times for the same entities. A simple panel regression model is given by:

$$
Y_{i t}=\alpha+\beta X_{i t}+\mu_{i t}(1)
$$

The following double log panel econometric model will be the basis of our analysis.

$$
E I W B_{i t}=\alpha_{i}+\beta_{1}\left(\ln G D P p c_{i t}\right)+\beta_{2}\left(\ln G D P p c_{i t}\right)^{2}+\beta_{3}\left(\ln U R B N_{i t}\right)+\beta_{4}\left(\ln P D N S_{i t}\right)+\mu_{i t}(2)
$$

Where the subscript $i$ denotes country $i$ and subscript $t$ denotes year $t$, EIWB shows the ecological intensity of the human well-being of country $i$ in year $t$, GDPpc is GDP per capita; $\mu$ is the error term; $U R B N$ is the percentage of people living in urban areas; and PDNS is the number of people living per square kilometer of the area. Since we transform all variables into a $\log$ form, the resulting coefficients of $\beta_{1}, \beta_{2}$ and $\beta_{3}$ will be the elasticity estimates. Hence a coefficient of the independent variable is the net percentage change in the dependent variable because of a $1 \%$ change in the independent variable. 


\section{Method of analysis}

In this study, we calculate the EIWB by using infant survival rate (ISR) as a wellbeing measure and EF per capita as an environmental stress indicator. Using Firebaugh and Beck's (1994) transformation, the infant mortality rate (IMR) is converted into ISR, calculated as:

$$
I S R=1-\left(\frac{I M R}{1000}\right)
$$

ISR is the probability of infant survival to one year of age: it thus allows IMR to code as a positive measure of well-being (Brady et al., 2007).

Further, a complication could arise while using a ratio as a dependent variable. The difference in the variation in the numerator and the denominator may cause the variable with the greater variation to dominate a ratio. In our data set the coefficient of variation for ISR is 0.03 , and the range is 867.8-996.6; the coefficient of variation for EF per capita is 0.53 and the range is $0.4-7.54$. Thus, variation in EF is larger than variation in ISR.

To resolve this complication, we add a constant (correction factor) ${ }^{9}$ to the numerator to limit the coefficient of variation of both the EF per capita (numerator) and ISR (denominator) to be equal, which shifts the mean without changing the variance. This approach for standardizing variables was developed by the New Economics Foundation (Abdallah et al., 2009). In our data set, the correction factor is 42.02 and we add this constant to the EF per capita. Hence, EIWB is:

$$
E I W B=\lfloor(E F \text { per capita }+42.02) / I S R\rfloor \times 100(4)
$$

Also, there is a possibility of multicollinearity if the squared term of a variable is included as an explanatory variable. Therefore, GDP per capita was centered by subtracting the mean and squaring the value - that is, the log of the GDP per capita is squared after subtracting the mean of the log of GDP per capita. This technique has been used in many EKC-based studies to reduce collinearity with GDP per capita (Dietz et al., 2012; Knight \& Rosa, 2009; York et al., 2003). We calculated the variance inflation factor (VIF), ${ }^{10}$ which is 1.74 , hence shows no evidence of multicollinearity. Here, we follow the conventional double logged approach and all data were transformed to the natural log before using them for the analysis. We have used statistical software Stata 13 (StataCorp, 2013) for model estimation.

9 The coefficient of variation (CV) is calculated as: standard deviation (S)/mean (M), and the correction factor $(\mathrm{CF})$ is calculated as:

$C F=\left(\frac{\left(S_{E F} \times M_{I S R}\right)}{S_{I S R}}\right)-M_{E F}$.

10 The variance inflation factor (VIF) is calculated as: $1 \div\left(1-\mathrm{R}^{2}\right)$. 
Table 1. Description of study variables

\begin{tabular}{|c|c|c|c|}
\hline Variable & Description & Transformation & Data Source \\
\hline \multicolumn{4}{|c|}{ Dependent variables } \\
\hline $\begin{array}{l}\text { Ecological } \\
\text { footprint (EF) per } \\
\text { capita }\end{array}$ & \begin{tabular}{|l|} 
Land area required to \\
support the resource \\
consumption of the \\
nation (in global hectares) \\
\end{tabular} & - & $\begin{array}{l}\text { National Footprints and } \\
\text { Biocapacity Accounts, } 2018 \\
\text { edition (Global Footprint } \\
\text { Network, 2018) }\end{array}$ \\
\hline $\begin{array}{l}\text { Infant mortality } \\
\text { rate (IMR) }\end{array}$ & $\begin{array}{l}\text { The number of infants } \\
\text { dying before one year of } \\
\text { age (per } 1,000 \text { ) }\end{array}$ & $\begin{array}{l}\text { Transformed into infant } \\
\text { survival rate (ISR): } \\
\text { (ISR = } 1-(\mathrm{IMR} / 1000)\end{array}$ & $\begin{array}{l}\text { World Development } \\
\text { Indicators (WDI database; } \\
\text { World Bank, n.d.) }\end{array}$ \\
\hline $\begin{array}{l}\text { Ecological } \\
\text { intensity of well- } \\
\text { being (EIWB) }\end{array}$ & The ratio of EF over ISR & $\begin{array}{l}\text { Ratio corrected for } \\
\text { variation in ecological } \\
\text { footprints, and logged }\end{array}$ & Authors' calculation \\
\hline \multicolumn{4}{|c|}{ Independent variables } \\
\hline GDP per capita & $\begin{array}{l}\text { GDP per capita based } \\
\text { on purchasing power } \\
\text { parity (in constant USD } \\
\text { 2011) }\end{array}$ & Logged & WDI database \\
\hline $\begin{array}{l}\text { Quadratic term of } \\
\text { GDP per capita }\end{array}$ & - & $\begin{array}{l}\text { The log of the GDP per } \\
\text { capita is squared after } \\
\text { subtracting the mean } \\
\text { of the log of GDP per } \\
\text { capita }\end{array}$ & WDI database \\
\hline Urbanization & $\begin{array}{l}\text { People living in urban } \\
\text { areas out of the total } \\
\text { population (\%) }\end{array}$ & Logged & WDI database \\
\hline $\begin{array}{l}\text { Population } \\
\text { density }\end{array}$ & $\begin{array}{l}\text { People living per square } \\
\text { kilometer of land area }\end{array}$ & Logged & WDI database \\
\hline
\end{tabular}

Source: See citations throughout table.

\section{Results and discussion}

Figure 1 plots EF against the ISR. The wider horizontal spread of EF as compared to ISR shows a wider variation among the sample nations in generating environmental stress. A vertical line indicates the recent estimate of global biocapacity per capita. ${ }^{11}$ Notably, EFs for developing countries have crossed this limit during the period studied.

The variation in ISR along this line shows that higher well-being is achievable while living within the ecological limits. This phenomenon shows a difference among the developing nations in placing environmental stress relative to well-being.

11 Biocapacity is the capacity of ecosystems to regenerate what people demand from those surfaces. Biocapacity is an ecosystems' capacity to produce biological materials used by people and to absorb waste material generated by humans, under current management schemes and extraction technologies. For more details and updates to data, see www.footprintnetwork.org/. 


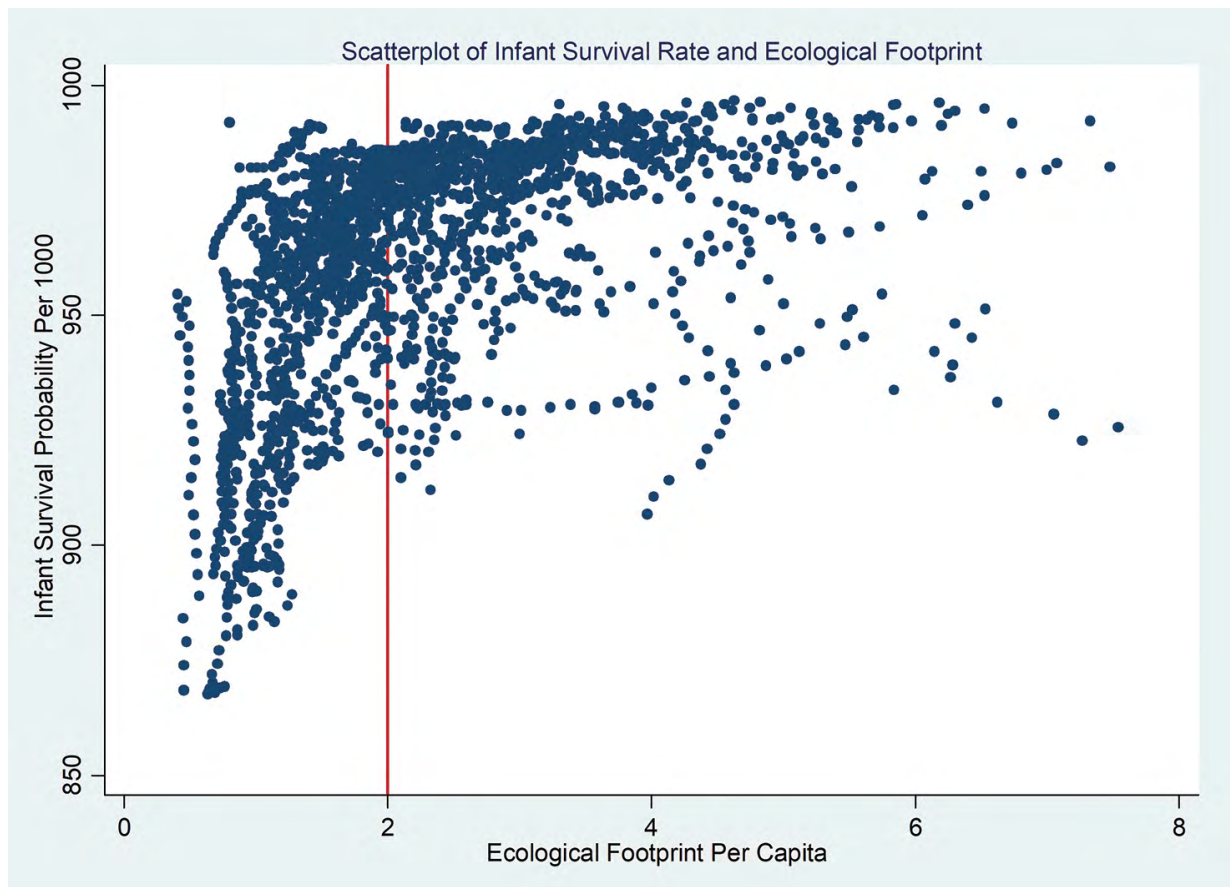

Figure 1. Scatterplot of infant survival probability (ISR) and ecological footprint (EF) per capita, 1989-2013

Note. The vertical line at 1.7 global hectares of EF is the global biocapacity per capita available.

Source: ISR data-World Development Indicators (World Bank, n.d., [Mortality rate, infant (per 1,000 live births)]). EF data-National Footprints and Biocapacity Accounts (Global Footprint Network, 2017).

Figure 2 plots EIWB by GDP per capita. The overall pattern of the graph is not an inverted U-shape, and thus contradicts the predictions of EKC. Rather it reveals a positive relationship between EIWB and the affluence levels of developing countries. In other words, the pattern shows that as the developing countries grow richer, stress on the ecosystem increases relative to the well-being generated.

Table 2 presents descriptive statistics of study variables. The study has estimated the fixed-effects and random-effects models, since the Hausman test favors a fixed-effects model $\left(p>X^{2}=.004\right)$. Panel regression estimates of the fixedeffect model are reported in Table 3. The fixed-effects model controls all countryspecific effects constant over time, such as climate (Aşıcı, 2013; Dietz et al., 2012). In Table 3, the overall R-square indicates $43 \%$ of the variation in EIWB explained in the model. 


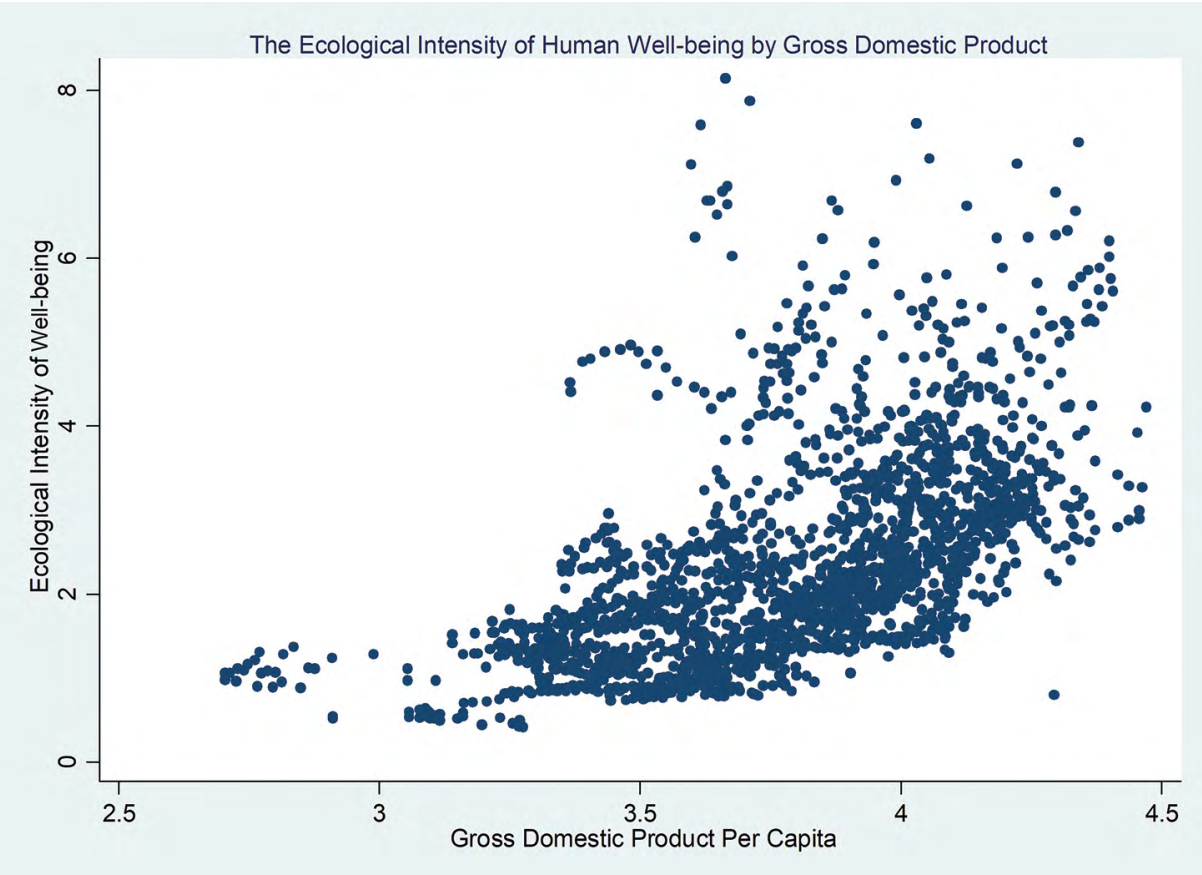

Figure 2. The ecological intensity of well-being (EIWB) by GDP per capita (1989-2013)

Source: Authors' findings.

Table 2. Descriptive properties of study variables

\begin{tabular}{|l|r|r|r|r|}
\hline Variable & Mean & Standard deviation & Minimum & Maximum \\
\hline Ecological intensity of well-being (EIWB) & 0.733 & 0.519 & -0.869 & 2.097 \\
\hline Log GDP per capita & 8.723 & 0.718 & 6.222 & 10.296 \\
\hline (Log GDP per capita) $^{\star}$ & 0.515 & 0.722 & $4.28 \mathrm{E}-07$ & 6.257 \\
\hline Urbanization & 3.885 & 0.405 & 2.597 & 4.555 \\
\hline Population density & 3.987 & 1.604 & 0.340 & 12.951 \\
\hline
\end{tabular}

Note. ${ }^{*} p>X^{2}=.004$

Source: Authors' description.

The regression results in Table 3 show that the coefficient of the linear term of GDP per capita is significant and positive, while the coefficient of the quadratic term of GDP per capita shows a positive but insignificant effect on EIWB. This finding suggests that EIWB increases with rising affluence levels, and no significant evidence in favor of the EKC hypothesis is found: a phenomenon consistent with the previous literature (Dietz et al., 2012; Knight \& Rosa, 2011). Therefore, developing countries are still lagging in reaching the critical GDP threshold after which EIWB 
may fall. We estimated another model by taking EIWB in terms of the ratio of EF and average life expectancy as the dependent variable (see Appendix Table 2). These estimation results also showed no evidence for the EKC phenomenon.

Table 3. Estimates of the fixed-effects model for ecological intensity of well-being (EIWB)

\begin{tabular}{|l|c|}
\hline Dependent variable EIWB (EF per capita/ISR) & Fixed-effects (within) regression \\
\hline Gross domestic product (GDP) & $.218^{* *}$ \\
& $(.014)$ \\
\hline Square term of GDP & .004 \\
& $(.003)$ \\
\hline Urbanization & $.192^{* *}$ \\
& $(.045)$ \\
\hline Population density & $-.129^{* *}$ \\
& $(.009)$ \\
\hline Constant & -.814 \\
& $(.058)$ \\
\hline R2 (within) & 0.196 \\
\hline R2 (between) & 0.455 \\
\hline Overall R2 & 0.428 \\
\hline Number of observations (81 countries, 25 years) & 2025 \\
\hline
\end{tabular}

Note. $\mathrm{EF}=$ ecological footprint. All variables are on a log scale. Values in parentheses are standard errors. ${ }^{*} p<.05 ;{ }^{* \star} p<.01$.

Source: Authors' estimates.

The coefficient of urbanization (percentage of the urban population in the total population) is 0.192 and significant. It shows that a $1 \%$ increase in urbanization increases EIWB by $0.19 \%$. The finding contradicts the ecological modernization theory, which suggests that environmental quality and related benefits improve as the societies are urbanized (York et al., 2003).

Besides, population density has a significant negative effect on EIWB, with a coefficient value of -0.129 . It suggests that a $1 \%$ increase in population density decreases EIWB by $0.129 \%$. While the effect of population density on EIWB has remained understudied so far, the findings of the present study show that EIWB becomes lower as people live more densely.

\section{Conclusion}

A substantial body of literature has conceptualized sustainability as the level of human well-being relative to environmental stress and enabled the cross-national assessment of sustainable development through carbon or ecological intensity of well-being - a concept that combines environmental and human well-being 
measures into one indicator. Countries with high well-being and low environmental impact have low EIWB, which is desirable for sustainability (Dietz et al., 2012; Jorgenson, 2014; Jorgenson \& Dietz, 2015).

The current study presents a revised measure of EIWB by taking the ratio of EF per capita as environmental stressor and ISR as well-being indicator, and examines the effect of key variables from a modernization perspective on the EIWB by using panel data of 81 developing countries from 1989 to 2013.

The panel fixed-effect regression estimates reveal that there is a significant positive relationship between GDP per capita and the dependent variable EIWB. But the relationship between the square term of GDP per capita and EIWB is noncurvilinear-contrary to the EKC phenomenon, which is a central idea in modernization theories relating growth and environmental stress. Also, we find that urbanization has a positive effect on EIWB. Modernization theories link higher well-being with a higher level of consumption and therefore argue for higher economic growth and urbanization for achieving sustainability (Knight \& Rosa, 2011; Mol \& Spaargaren, 2004; York et al., 2003). However, our findings suggest that with an increase in the level of economic development and urbanization in developing nations, anthropogenic environmental stress relative to well-being also increases.

Further, we find that population density has a negative (i.e., desirable) and significant effect on EIWB. This finding suggests that if a population lives more densely, this could be a way forward for sustainable development. Future research linking density and sustainability can provide a better understanding of the potential for population density to reduce EIWB and guidance to the path of sustainability.

Overall, the study provides important insights for developing nations to review and strengthen their modernization policies, keeping in view their performance towards the key challenges of sustainability_minimizing environmental stress and increasing human well-being.

Our analysis extends the ongoing work on EIWB and provides initial estimates for developing countries rather than definite findings. The nature of analysis encourages more refined work and suggests a range of future research avenues. Here, we find the environmental Kuznets curve argument inadequate for developing countries. However, fresh insights may be expected by taking alternative measures of wellbeing, ecological stress indicators, and other institutional, cultural, and social factors influencing environmental stress and shaping human well-being. 


\section{Acknowledgment}

We wish to acknowledge the anonymous reviewers for their comments, and the Global Footprint Network for providing the 2018 edition of the EF data package ahead of publication.

\section{References}

Abdallah, S., Thompson, S., Michaleson, J., Marks, N., \& Steuer, N. (2009). The happy planet index 2.0: Why good lives don't have to cost the Earth. The New Economics Foundation. Available at neweconomics.org/2009/06/happy-planet-index-2-0

Aşıc1, A. A. (2013). Economic growth and its impact on environment: A panel data analysis. Ecological Indicators, 24, 324-333. doi.org/10.1016/j.ecolind.2012.06.019

Bay, J. H. P., \& Lehmann, S. (2017). Growing compact: Urban form, density and sustainability. Taylor \& Francis. doi.org/10.4324/9781315563831

Borucke, M., Moore, D., Cranston, G., Gracey, K., Iha, K., Larson, J., ... Galli, A. (2013). Accounting for demand and supply of the biosphere's regenerative capacity: The National Footprint Accounts' underlying methodology and framework. Ecological Indicators, 24, 518-533. doi.org/10.1016/j.ecolind.2012.08.005

Brady, D., Kaya, Y., \& Beckfield, J. (2007). Reassessing the effect of economic growth on well-being in less-developed countries, 1980-2003. Studies in Comparative International Development, 42(1-2), 1-35. doi.org/10.1007/s12116-007-9003-7

Commoner, B. (1972). The environmental cost of economic growth. Chemistry in Britain, $8(2), 52-56$.

Commoner, B., Ehrlich, P. R, \& Holdren, J. P. (1972). A bulletin dialogue on "The Closing Circle": Response. Bulletin of the Atomic Scientists, 28(5), 17-56. doi.org/10.1080/0096 3402.1972.11457931

Costanza, R., Hart, M., Talberth, J., \& Posner, S. (2009, January). Beyond GDP: The need for new measures of progress (The Pardee Papers, no. 4). The Frederick S. Pardee Center for the Study of the Longer-Range Future, Boston University. www.bu.edu/pardee/files/ documents/PP-004-GDP.pdf?PDF=pardee-paper-004-beyond-gdp

Dietz, T., Rosa, E. A., \& York, R. (2007). Driving the human ecological footprint. Frontiers in Ecology and the Environment, 5(1), 13-18. doi.org/10.1890/1540-9295(2007)5 [13:DTHEF]2.0.CO;2

Dietz, T., Rosa, E. A., \& York, R. (2009). Environmentally efficient well-being: Rethinking sustainability as the relationship between human well-being and environmental impacts. Human Ecology Review, 16(1), 114-123. www.jstor.org/stable/24707742 
Dietz, T., Rosa, E. A., \& York, R. (2012). Environmentally efficient well-being: Is there a Kuznets curve? Applied Geography, 32(1), 21-28. doi.org/10.1016/j.apgeog.2010.10.011

Dietz, T., York, R., \& Rosa, E. A. (2001, October 8). Ecological democracy and sustainable development [Paper presentation]. Open Meeting of the Human Dimensions of Global Environmental Change Research Community, Rio de Janeiro, Brazil.

Ehrlich, P. R., \& Holdren, J. P. (1971). Impact of population growth. Science, 171(3977), 1212-1217. doi.org/10.1126/science.171.3977.1212

European Commission. (2009, August 20). GDP and beyond: Measuring progress in a changing world (Report No. COM(2009) 433) [Policy Document]. www.eea.europa.eu/ policy-documents/com-2009-433-final-gdp

Fiala, N. (2008). Measuring sustainability: Why the ecological footprint is bad economics and bad environmental science. Ecological Economics, 67(4), 519-525. doi.org/10.1016/ j.ecolecon.2008.07.023

Firebaugh, G., \& Beck, F. D. (1994). Does economic growth benefit the masses? Growth, dependence, and welfare in the third world. American Sociological Review, 59(5), 631-653. doi.org/10.2307/2096441

Galli, A., Giampietro, M., Goldfinger, S., Lazarus, E., Lin, D., Saltelli, A., ... Müller, F. (2016). Questioning the ecological footprint. Ecological Indicators, 69, 224-232. doi.org/ 10.1016/j.ecolind.2016.04.014

Giampietro, M., \& Mayumi, K. (2009). The biofuel delusion: The fallacy of large scale agrobiofuels production. Routledge. doi.org/10.4324/9781849770200

Giampietro, M., \& Saltelli, A. (2014). Footprints to nowhere. Ecological Indicators, 46, 610-621. doi.org/10.1016/j.ecolind.2014.01.030

Global Footprint Network. (2017). National footprints and biocapacity accounts (2017 edition) [Data set]. data.world/footprint/nfa-2017-edition

Global Footprint Network. (2018). National footprints and biocapacity accounts (2018 edition) [Data set]. data.world/footprint/nfa-2018-edition

Grossman, G. M., \& Krueger, A. B. (1995). Economic growth and the environment. The Quarterly Journal of Economics, 110(2), 353-377. doi.org/10.2307/2118443

Hanmer, L., Lensink, R., \& White, H. (2003). Infant and child mortality in developing countries: Analysing the data for robust determinants. The Journal of Development Studies, 40(1), 101-118. doi.org/10.1080/00220380412331293687

Jorgenson, A. K. (2014). Economic development and the carbon intensity of human wellbeing. Nature Climate Change, 4(3), 186-189. doi.org/10.1038/nclimate2110

Jorgenson, A. K., \& Clark, B. (2011). Societies consuming nature: A panel study of the ecological footprints of nations, 1960-2003. Social Science Research, 40(1), 226-244. doi.org/10.1016/j.ssresearch.2010.09.004 
Jorgenson, A. K., \& Dietz, T. (2015). Economic growth does not reduce the ecological intensity of human well-being. Sustainability Science, 10(1), 149-156. doi.org/10.1007/ s11625-014-0264-6

Knight, K. W., \& Rosa, E. A. (2009, October 15-17). The environmental costs of life satisfaction: A cross-national empirical test [Paper presentation]. SCORAI Workshop on Individual Consumption and Systemic Societal Transformation, Clark University, Worcester, Massachusetts.

Knight, K. W., \& Rosa, E. A. (2011). The environmental efficiency of well-being: A cross-national analysis. Social Science Research, 40(3), 931-949. doi.org/10.1016/ j.ssresearch.2010.11.002

Lamb, W. F., Steinberger, J. K., Bows-Larkin, A., Peters, G. P., Timmons Roberts, J., \& Wood, F. R. (2014). Transitions in pathways of human development and carbon emissions. Environmental Research Letters, 9(1), 014011. doi.org/10.1088/1748-9326/9/1/014011

Layard, R. (2010). Measuring subjective well-being. Science, 327(5965), 534-535. doi.org/ $10.1126 /$ science. 1186315

Lin, D., Hanscom, L., Murthy, A., Galli, A., Evans, M., Neill, E., ... Wackernagel, M. (2018). Ecological footprint accounting for countries: updates and results of the National Footprint Accounts, 2012-2018. Resources, 7(3), Article 58. doi.org/10.3390/ resources 7030058

Marks, N., Abdallah, S., Sims, A., \& Thompson, S. (2006). The happy planet index: An index of human well-being and environmental impact. New Economics Foundation. neweconomics. org/uploads/files/54928c89090c07a78f_ywm6y59da.pdf

Martínez-Zarzoso, I., \& Maruotti, A. (2011). The impact of urbanization on $\mathrm{CO}_{2}$ emissions: Evidence from developing countries. Ecological Economics, 70(7), 1344-1353. doi.org/ 10.1016/j.ecolecon.2011.02.009

Meadows, D. H., Meadows, D. L., Randers, J., \& Behrens III, W. W. (1972). The limits to growth: A report to the club of Rome. Universe Books.

Mol, A. P. J., \& Sonnenfeld, D. A. (Eds.). (2000). Ecological modernization around the world: Perspectives and critical debates. Frank Cass.

Mol, A. P. J., \& Spaargaren, G. (2000). Ecological modernisation theory in debate: A review. Environmental Politics, 9(1), 17-49. doi.org/10.1080/09644010008414511

Mol, A. P. J., \& Spaargaren, G. (2004). Ecological modernization and consumption: A reply. Society and Natural Resources, 17(3), 261-265. doi.org/10.1080/08941920490270302

National Research Council. (1997). Environmentally significant consumption: Research directions. National Academies Press. doi.org/10.17226/5430

Özler, Ş. İ., \& Obach, B. K. (2009). Capitalism, state economic policy and ecological footprint: An international comparative analysis. Global Environmental Politics, 9(1), 79-108. doi.org/10.1162/glep.2009.9.1.79 
Prescott-Allen, R. (2001). Wellbeing of nations: A country-by-country index of quality of life and the environment. International Development Research Centre. hdl.handle. net/10625/19881

Pritchett, L., \& Summers, L. (1996). Wealthier is happier. Journal of Human Resources, 31(4), 841-868. doi.org/10.2307/146149

Ravallion, M. (1997). Good and bad growth: The human development reports. World Development, 25(5), 631-638. doi.org/10.1016/s0305-750x(96)00141-6

Rees, W. E. (1996). Revisiting carrying capacity: Area-based indicators of sustainability. Population and Environment, 17(3), 195-215. doi.org/10.1007/bf02208489

Rees, W. E. (2006). Ecological footprints and biocapacity: Essential elements in sustainability assessment. In J. Dewulf \& H. van Langenhove (Eds.), Renewables-based technology: Sustainability assessment (pp. 143-157). John Wiley \& Sons Ltd. doi.org/ 10.1002/0470022442.ch9

Reidpath, D. D., \& Allotey, P. (2003). Infant mortality rate as an indicator of population health. Journal of Epidemiology \& Community Health, 57(5), 344-346. doi.org/10.1136/ jech.57.5.344

Seyfang, G. (2009). The new economics of sustainable consumption: Seeds of change. Palgrave Macmillan.

Shafik, N. (1994). Economic development and environmental quality: An econometric analysis. Oxford Economic Papers, 46(1), 757-773. doi.org/10.1093/oep/46.supplement _1.757

StataCorp. (2013). Stata [Statistical software] (Release 13). StataCorp LP. www.stata.com/

Steinberger, J. K., \& Timmons Roberts, J. (2010). From constraint to sufficiency: The decoupling of energy and carbon from human needs, 1975-2005. Ecological Economics, 70(2), 425-433. doi.org/10.1016/j.ecolecon.2010.09.014

Steinberger, J. K., Timmons Roberts, J., Peters, G. P., \& Baiocchi, G. (2012). Pathways of human development and carbon emissions embodied in trade. Nature Climate Change, 2(2), 81-85. doi.org/10.1038/nclimate1371

Stern, D. I., Common, M. S., \& Barbier, E. B. (1996). Economic growth and environmental degradation: the environmental Kuznets curve and sustainable development. World Development, 24(7), 1151-1160. doi.org/10.1016/0305-750x(96)00032-0

Timmons Roberts, J., \& Grimes, P. E. (1997). Carbon intensity and economic development 1962-1991: A brief exploration of the environmental Kuznets curve. World Development, 25(2), 191-198. doi.org/10.1016/s0305-750x(96)00104-0

United Nations. (2015). Millennium Development Goals report 2015. Available at www. un.org/millenniumgoals/ 
United Nations. (2020). Ensure healthy lives and promote well-being for all at all ages. Sustainable Development, United Nations Department of Economic and Social Affairs. sdgs.un.org/goals/goal3

United Nations Conference on Environment and Development. (1992). Agenda 21: The Rio declaration on environment and development. United Nations. sustainabledevelopment. un.org/outcomedocuments/agenda21

United Nations Development Programme. (2009). Overcoming barriers: Human mobility and development (Human development report 2009). hdr.undp.org/en/content/humandevelopment-report-2009

World Bank. (n.d.). World Development Indicators [Mortality rate, infant (per 1,000 live births); GDP per capita, PPP (constant 2011 international \$); Urban population (\% of total population); Population density (people per sq. $\mathrm{km}$ of land area)]. Retrieved January 3, 2018, from databank.worldbank.org/source/world-development-indicators

World Bank. (2015). Historical classifications by income [Data set]. Available at datahelpdesk. worldbank.org/knowledgebase/articles/906519-world-bank-country-and-lendinggroups

York, R., Rosa, E. A., \& Dietz, T. (2003). Footprints on the earth: The environmental consequences of modernity. American Sociological Review, 68(2), 279-300. doi.org/ $10.2307 / 1519769$

York, R., Rosa, E. A., \& Dietz, T. (2004). The ecological footprint intensity of national economies. Journal of Industrial Ecology, 8(4), 139-154. doi.org/10.1162/1088198043 630487

\section{Appendix}

\section{Appendix Table 1. Countries included in the analysis}

\begin{tabular}{|l|l|l|}
\hline Albania & Grenada & Paraguay \\
\hline Algeria & Guatemala & Peru \\
\hline Angola & Guyana & Philippines \\
\hline Argentina & Honduras & Republic of the Congo \\
\hline Armenia & India & Romania \\
\hline Azerbaijan & Indonesia & Russian Federation \\
\hline Belarus & Iran, the Islamic Republic of & Saint Kitts and Nevis \\
\hline Bhutan & Iraq & Saint Lucia \\
\hline Bolivia & Jamaica & Samoa \\
\hline Botswana & Jordan & São Tomé and Príncipe \\
\hline Brazil & Lao People's Democratic Republic & Senegal \\
\hline Bulgaria & Latvia & South Africa \\
\hline
\end{tabular}


The Ecological Intensity of Well-Being in Developing Countries

\begin{tabular}{|l|l|l|}
\hline Cameroon & Lebanon & Sri Lanka \\
\hline Cape Verde & Lesotho & Suriname \\
\hline China & Lithuania & Swaziland \\
\hline Colombia & Macedonia, the Republic of North & Thailand \\
\hline Costa Rica & Malaysia & Tonga \\
\hline Côte d'Ivoire & Mauritania & Tunisia \\
\hline Djibouti & Mauritius & Turkey \\
\hline Dominica & Mexico & Turkmenistan \\
\hline Dominican Republic & Moldova & Ukraine \\
\hline Ecuador & Mongolia & Uruguay \\
\hline Egypt & Morocco & Uzbekistan \\
\hline El Salvador & Nicaragua & Venezuela, the Bolivarian Republic of \\
\hline Fiji & Nigeria & Viet Nam \\
\hline Georgia & Pakistan & Yemen \\
\hline Ghana & Panama & Zambia \\
\hline
\end{tabular}

Source: World Bank (2015).

Appendix Table 2. Random effect model ecological intensity of well-being (EIWB) (environmental footprint per capita/average life expectancy)

\begin{tabular}{|l|c|}
\hline $\begin{array}{l}\text { Dependent variable EIWB (EF per capita/average } \\
\text { life expectancy }\end{array}$ & Fixed effects (within) regression \\
\hline GDP & $\begin{array}{c}0.0799^{\star} \\
(.039)\end{array}$ \\
\hline Square term of GDP & .0096 \\
& $(.011)$ \\
\hline Urbanization & $.055^{*}$ \\
& $(.012)$ \\
\hline Population density & $-.010^{\star *}$ \\
& $(.002)$ \\
\hline Constant & -.814 \\
& $(.058)$ \\
\hline$R^{2}$ (within) & 0.2176 \\
\hline$R^{2}$ (between) & 0.4106 \\
\hline Overall R & 0.3918 \\
\hline Number of observations $(81$ countries, 25 years) & 2025 \\
\hline
\end{tabular}

Note. ${ }^{*} p<.05 ;{ }^{* *} p<.01$.

Source: Authors' results. 
This text is taken from Human Ecology Review, Volume 27, Number 1, 2021, published by ANU Press, The Australian National University, Canberra, Australia. doi.org/10.22459/HER.27.01.2021.05 